\title{
PEMANFAATAN SISTEM INFORMASI GEOGRAFIS DALAM EVALUASI KINERJA PENYEDIAAN AIR MINUM PERPIPAAN (STUDI KASUS SISTEM LENDAH KABUPATEN KULON PROGO)
}

\author{
Angga Budi Kusuma1 \\ ${ }^{1}$ Badan Pengembangan Infrastruktur Wilayah, \\ Kementerian Pekerjaan Umum dan Perumahan Rakyat \\ Jl. Pattimura, Kebayoran Baru, Jakarta Selatan, DKI Jakarta 1211 \\ Email: angga.budi.kusuma@gmail.com
}

\begin{abstract}
Abstrak
Evaluasi jaringan perpipaan merupakan bagian dari evaluasi kinerja penyediaan air minum. Sistem Informasi Geografis (SIG) memberikan informasi akurat mengenai informasi kebumian dan integrasinya dengan Epanet memberikan efisiensi dalam evaluasi jaringan perpipaan. Jaringan Perpipaan Sistem Lendah merupakan jaringan distribusi air minum dengan sistem pompa-gravitasi dengan sumber air baku Sungai Progo. Hasil analisis menunjukan bahwa Sistem Lendah mampu menyediakan kebutuhan air minum selama 24 jam. Sisa tekanan air di beberapa lokasi sangat tinggi diatas persyaratan menyebebabkan rentan kebocoran. Kecepatan aliran di beberapa ruas pipa masih dibawah kecepatan yang dipersyaratkan menyebabkan potensi pengendapan dalam pipa. Beberapa solusi dapat digunakan untuk mengatasi permasalahan tersebut dengan mengganti jenis pipa, mengganti diameter pipa sesuai dengan kriteria, menambahkan bak pelepas tekanan (BTP) atau pressure reducing valve (valve) untuk mengurangi sisa tekanan di beberapa titik.
\end{abstract}

Kata Kunci: Sistem Informasi Geografis, Epanet, Sistem Lendah, Jaringan Perpipaan

\begin{abstract}
Pipe network evaluation is a part of evaluation of drinking water supply performance. Geographic Information System (GIS) provides accurate information about earth and its integration with Epanet gives eficiency in pipe network evaluation. Lendah system pipe network is drinking water distribution networks with pump-gravitation system and water of Progo River as the water source. The analyst shows that Lendah System is capable of providing drinking water needs 24 hours daily. The remaining water pressure in several locations are exceeded standard causing leakage vulnerability. Water velocity of several pipe segments is below required velocity. Several solutions could be taken to solve those problems they change pipe type, change pipe diameter suited to standard, add pressure release tube (PRT) or pressure reducing valve (valve) to reduce remaining pressure in several nodes.
\end{abstract}

Keywords: Geographic Information Systems, Epanet, Lendah System, Pipe Network

\section{PENDAHULUAN}

Air merupakan bagian penting dari hidup manusia. Air saat ini sangat dirasakan memiliki nilai ekonomi yang besar dan banyak pihak yang memperebutkan untuk menguasai sumber-sumbernya (Lukenga, 2015).
Kejadian kekurangan air memiliki efek yang berbeda di berbagai wilayah, di sebuah wilayah penduduknya hanya kekurangan air merupakan fenomena rutin dan dianggap maklum, sedangkan ditempat lain kekurangan air hanya terjadi dalam periode pendek dan bisa 


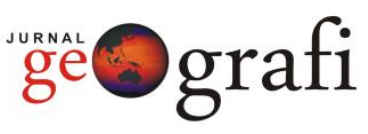

menyebabkan kekacauan (Chandapillai et al, 2011). Dari sini peran pemerintah sebagai perwakilan dari masyarakat wajib mengatur pemanfaatan dan penyediaan air untuk kebutuhan sehari-hari. Berdasarkan PP 122 Tahun 2015 tentang Sistem Penyediaan Air Minum menjelaskan bahwa penyediaan air untuk memenuhi kebutuhan hidup sehari-hari masyarakat yang digunakan untuk keperluan minum, masak, mandi, cuci, peturasan, dan ibadah masuk kedalam kegiatan penyediaan air minum.

Secara umum penyediaan air minum terdiri dari unit produksi dan unit distribusi. Unit distribusi diarahkan menggunakan sistem tertutup atau perpipaan supaya tidak terjadi kontaminasi pada air yang didistribusikan (Dharmasetiawan, 1993). Tujuan utama dari distribusi air minum adalah untuk mengalirkan air yang berasal dari unit pengolahan air kepada konsumen dengan kuantitas, kualitas, dan tekanan yang cukup. Di dalam proses selama distribusi air minum kondisi air minum dapat saja mengalami penurunan kualitas akibat reaksi antara air dengan jaringan air ataupun adanya intrusi air tanah ke dalam jaringan distribusi (National Research Council, 2006).

Dalam pembangunan dan evaluasi jaringan perpipaan dibutuhkan sebuah alat yang dapat menyelesaikan permasalahan secara cepat. Secara teknis pembangunan jaringan perpipaan juga mempertimbang-kan kondisi geografis utamanya ketinggian.

Sistem Informasi Geografis (SIG) merupakan sebuah alat yang memiliki kemampuan tinggi untuk menyelesaikan masalah-masalah di bidang penyediaan air minum. Secara umum definisi SIG adalah sebuah sistem yang terdiri dari hardware, software, data, manusia, organisasi, dan institusi untuk mengumpulkan, menyimpan, menganalisis, mempublikasi-kan informasi tentang kebumian (Dueker dan Kjerne, 1989). Ahli hidrologi telah banyak memanfaatkan SIG untuk melakukan analisis penyediaan air, prediksi banjir, penilaian dampak lingkungan. Salah satu bagian dari SIG yang sangat membantu adalah analisis 3D dimana menghasilkan data DEM (Digital Elevation Models) (Maidment, 2002).

Perencanaan berbasis jaringan dengan memanfaatkan SIG sudah banyak diterapkan di berbagai bidang infrastrutur. Awalin dan Sukojo (2003) melakukan analisa jaringan distribusi listrik. Sedangkan Rachmawati (2010) memanfaatkan SIG untuk mengevaluasi jaringan drainase. Persamaan diantara pemanfaatkan SIG tersebut bahwa dalam melakukan analisis peneliti harus memahami variabel dan perhitungan teknis yang mempengaruhi kinerja infrastruktur tersebut.

Pemanfaatan SIG dalam evaluasi jaringan perpipaan biasanya terbagi menjadi 2 bagian, yang pertama adalah mengintegrasikan software SIG dengan software analisis jaringan air minum dan yang kedua membuat kode pemrograman dalam software SIG yang dapat menganalisis jaringan air minum.

Shen dan McBean (2010) melakukan penelitian mengenai identifikasi kontaminan air di dalam jaringan perpipaan dengan menggunakan ArcGis yang telah ditambah kode pemograman yang dapat menampilkan GUI (Graphical User Interface). GUI ini mampu mengintegrasikan berbagai data dalam ArcGis dan menampilkannya dalam bentuk visual. Nguyen Giang et al (2015) membuat sebuah program terintegrasi antara dalam model Epanet dan GIS yang dilakukan HPC (High Performance Computer). Sistem ini mampu mengolah data kompleks dalam waktu yang singkat dimana komputer biasa tidak mampu menyelesaikannya secara singkat.

Cara pertama memang membutuhkan waktu agak lama akan tetapi pengguna tidak perlu bersusah payah dalam membuat bahasa pemrograman dan menata data. Akan tetapi dibutuhkan software tambahan yang 
mampu mengkonversi data dari software GIS ke software jaringan air minum dan sebaliknya. Evaluasi jaringan air minum perpipaan menggunakan Epanet akan lebih akurat jika didukung data geografis yang akurat. Pengolahan data geografis secara cepat dan efektif membutuhkan bantuan program SIG yang mumpuni. Mohaptra (2013) menggunakan bantuan ArcGis untuk membangkitkan data ketinggian titik kebutuhan dan peta yang dibuat dengannya dikonversi ke dalam bentuk file Epanet.

\section{METODE PENELITIAN}

Perangkat lunak SIG yang digunakan dalam penelitian ini adalah ArcGis. ArcGis merupakan software buatan ESRI yang banyak digunakan di Indonesia. Software evaluasi jaringan perpipaan menggunakan Epanet. Epanet merupakan software freeware buatan Environmental Protection Agency (EPA).
Epanet adalah program yang menggambarkan simulasi hidraulis dan kecenderungan kualitas air yang mengalir di dalam pipa.

Epanet dibuat sebagai alat untuk memahami pergerakan air di dalam pipa dan kandungannya. Cakupan kemampuan Epanet antara lain (Rossman, 2000).

- Alternatif penggunaan sumber air dalam berbagai sumber dalam satu sistem.

- Alternatif pemompaan dalam pemompaan dan penjadwalan pengisikan tanki.

- Penggunaan pengolahan air salah satunya pemberian khlorin sebagai desinfektan dalam tanki penyimpanan air.

- Mengidentifikasi pipa yang membutuhkan pembersihan dan penggantian.

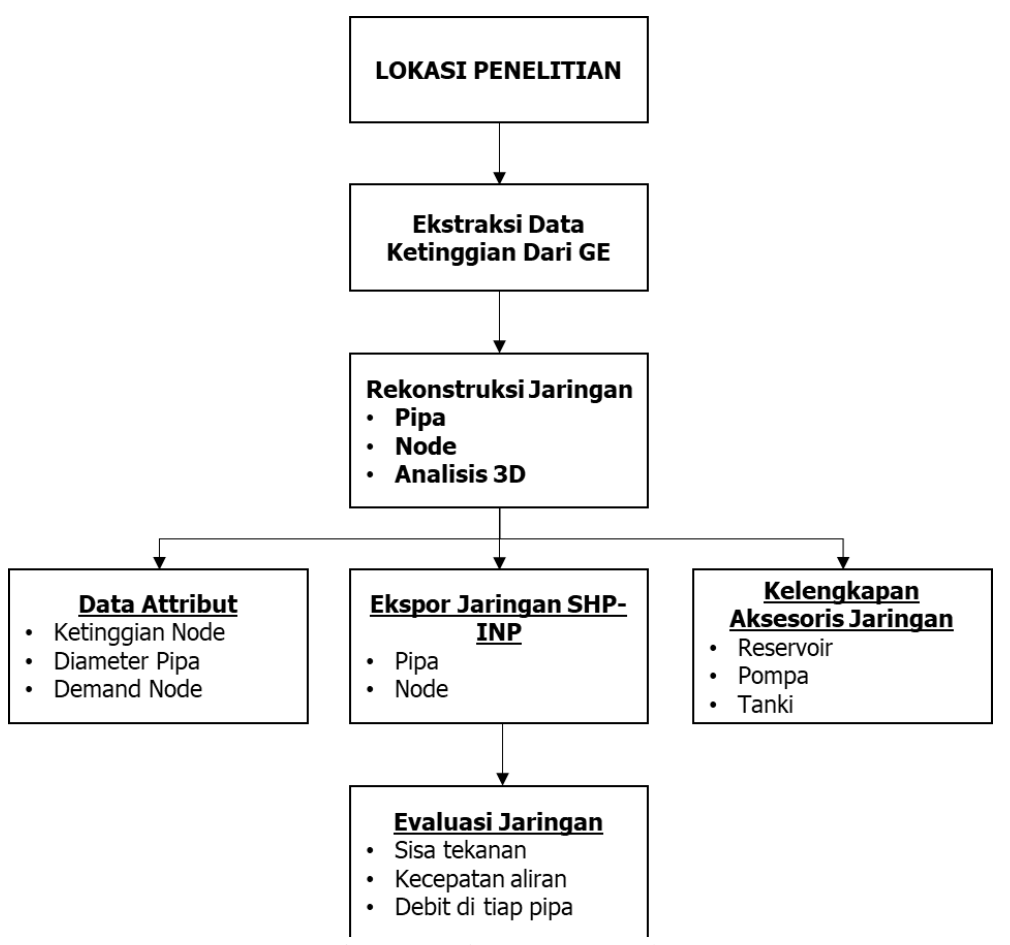

Gambar 1. Skema Penelitian

Data topografi yang digunakan untuk memberikan informasi ketinggian pada jaringan perpipaan menggunakan data DEM. Data DEM ini memanfaatkan informasi ketinggian yang diekstrak dari Google Earth.
Google Earth (GE) merupakan perangkat lunak buatan Google.inc yang menyediakan tampilan citra google satellite. Selain itu Google.inc juga memiliki Google Maps yang saat ini digunakan secara luas bersamaan dengan meluasnya 


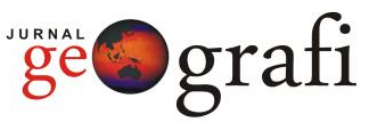

penggunaan smartphone. Keunggulan dari Google Earth adalah memiliki fleksibilitas dan lebih interaktif dibanding Google Maps karena tidak terbatas tampilannya pada web browser dan java script.

Penggunaan Google Earth sebagai sumber data ketinggian untuk menyiasati ketiadaan data ketinggian yang akurat. Wang et al (2017) mengemukakan bahwa data ketinggian dari GE memiliki nilai kesalahan rata-rata sebesar 1,32 meter. Nilai ini lebih baik dibandingkan data ketinggian yang didapatkan dari citra USGS dengan resolusi 30 meter. Sehingga pemanfaatan GE merupakan solusi alternatif yang cepat untuk mendapatkan data ketinggian. Pengambilan data ketinggian selama ini menggunakan pengambilan data titik manual satu persatu dan mereka-reka seperti yang dilakukan oleh Maulana (2014) dan Driyono (2016). Dalam penelitian ini digunakan TCX converter yang mampu mengekstrak data ketinggian sesuai dengan ketelitian yang kita inginkan sesuai cakupan wilayah kajian.

Kriteria dalam mengevaluasi jaringan perpipaan dijelaskan oleh Permen Pekerjaan Umum dan Perumahan Rakyat Nomor 27 Tahun 2016 tentang Penyelenggaraan Sistem Penyediaan Air Minum ditampilkan pada Tabel 1.

Tabel 1. Kriteria Pipa Distribusi

\begin{tabular}{|c|c|c|}
\hline No & Uraian & Kriteria \\
\hline 1 & Kecepatan Minimum & 0,3-0,6 m/detik \\
& Kecepatan Maksimum & \\
& • Pipa PVC & $3,0-4,5 \mathrm{~m} /$ detik \\
& - Pipa DCIP & $6 \mathrm{~m} /$ detik \\
\hline 2 & Tekanan Air dalam pipa & \\
& Tekanan Minimum & $1 \mathrm{~atm}=10 \mathrm{mH}_{2} \mathrm{O}$ \\
& Tekanan Maksimum & \\
& • Pipa PVC & $6-8 \mathrm{~atm}$ \\
& - Pipa DCIP & $10 \mathrm{~atm}$ \\
& - Pipa PE 100 & $12 \mathrm{mPa}$ \\
& - Pipa PE 80 & $9.0 \mathrm{mPa}$ \\
\hline
\end{tabular}

Sumber: Permen PUPR No.27 Tahun 2016

Penelitian ini dilakukan pada sistem Lendah pada PDAM (Perusahaan Daerah Air Minum Kulon Progo). PDAM ini merupakan perusahaan daerah yang bertanggung jawab untuk menyediakan air minum bagi penduduk di Kabupaten Kulon Progo. Perusahaan ini selain menyediakan air minum untuk kebutuhan domestik, juga menyediakan air minum untuk kegiatan pemerintahan dan industri.

Sistem Lendah memiliki layanan utama untuk melayani Kecamatan Lendah dan Kecamatan Galur. Akan tetapi pengembangannya sistem ini akan melayani calon bandara baru Kulon Progo dan kawasan pesisir selatan Kulon Progo yang kawasan tersebut akan menjadi kawasan pengembangan ekonomi antara lain sebagai kawasan aeropolis, kawasan industri pasir besi, dan kawasan pariwisata (Bappeda Kulon Progo, 2014).

Sistem ini sementara memiliki kapasitas produksi 80 liter/detik. Sumber air baku menggunakan Sungai Progo yang membatasi Kabupaten Kulon Progo dengan Kabupaten Bantul. Untuk memenuhi peningkatan permintaan air minum diharapkan dengan pembangunan Bendungan Kamijoro maka terdapat penambahan kapasitas produksi sebesar 300 l/detik. 


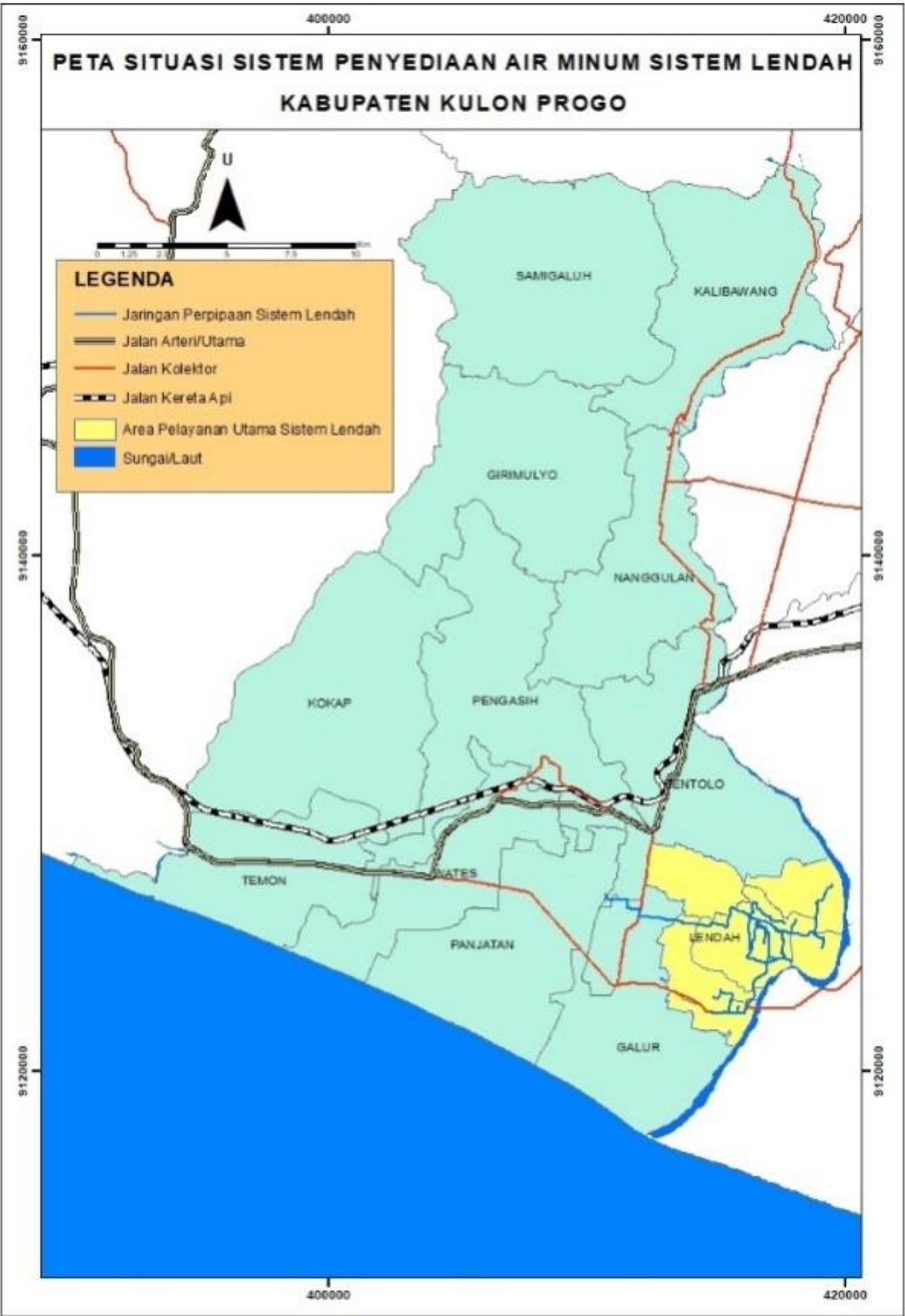

Gambar 2. Peta Lokasi Sistem Lendah

Akibat sebagian besar lokasi pelayanan memiliki elevasi yang lebih tinggi dibanding lokasi produksi, maka sistem ini menggunakan sistem gabungan pemompaan dan gravitasi. Air hasil produksi pada instalasi pengolahan dipompa menuju tanki. Dari tanki air akan dialirkan secara gravitasi kepada pelanggan. Skema distribusi air minum Sistem Lendah dapat dilihat pada Gambar 3 berikut. 


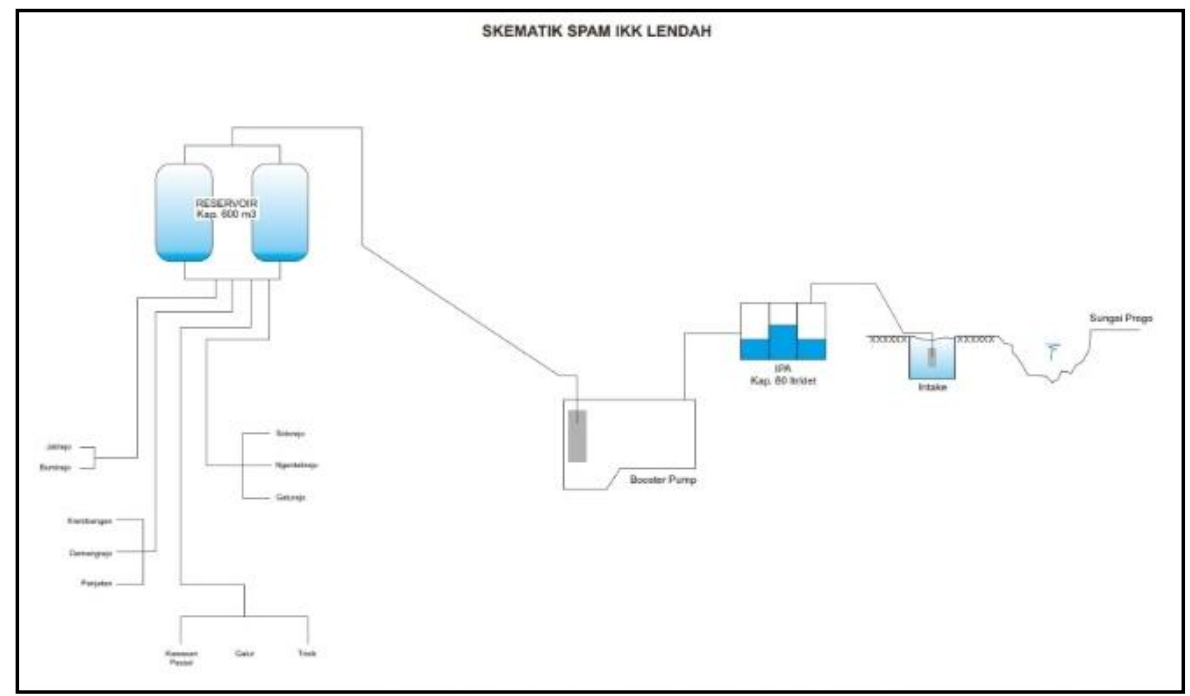

Gambar 3. Skema Ditribusi Air Minum Sistem Lendah

\section{HASIL DAN PEMBAHASAN}

Hasil ekstraksi data ketinggian dari GE yang dinterpolasi oleh TCX converter menghasilkan data titik-titik ketinggian dalam bentuk basis data. Informasi ini dapat ditampilkan di ArcGIS dan divisualisasikan selama memiliki informasi koordinat $(x, y)$ ditambah dengan data ketinggian. Setelah divisualisasikan data ini dikonversikan menjadi data DEM dalam bentuk TIN (Triangulated Irregular Network). Data TIN memiliki keunggulan tampilannya untuk memberikan informasi visualisasi lebih baik, mudah untuk dilakukan transformasi dan proyeksi dibanding data raster (Kreveld, 1997).

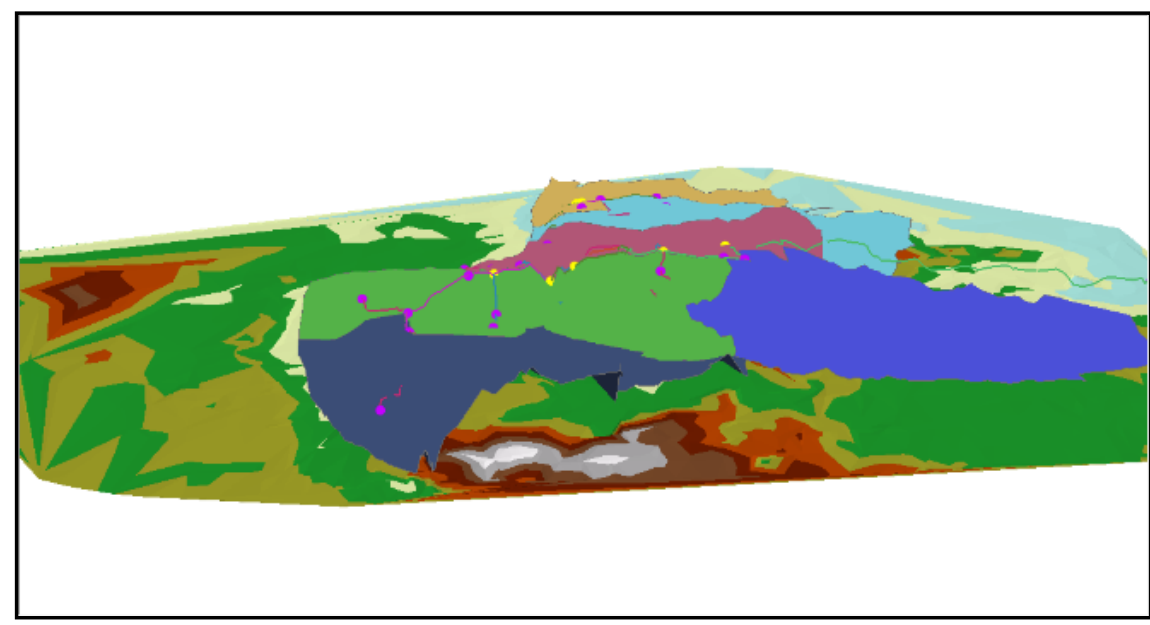

Gambar 4. Tampilan 3D Jaringan Sistem Lendah

Dari data TIN yang sudah dihasilkan kemudian diinterpolasikan dengan node. Sehingga setiap node memiliki informasi ketinggian. Selain data jaringan yang sudah dibuat dikoversi menjadi data input Epanet. Kelemahan dari proses ini data yang dikenali pada format baru hanyalah node dan pipa sesuai tampilan lokasi yang dibuat pada program ArcGis. Konversi ini tidak dapat mengenali penamaan node, pipa sampai atribut penting lainnya seperti diameter pipa, kebutuhan tiap node, dan aksesoris jaringan pipa seperti pompa, tanki, reservoir dan lainnya. 


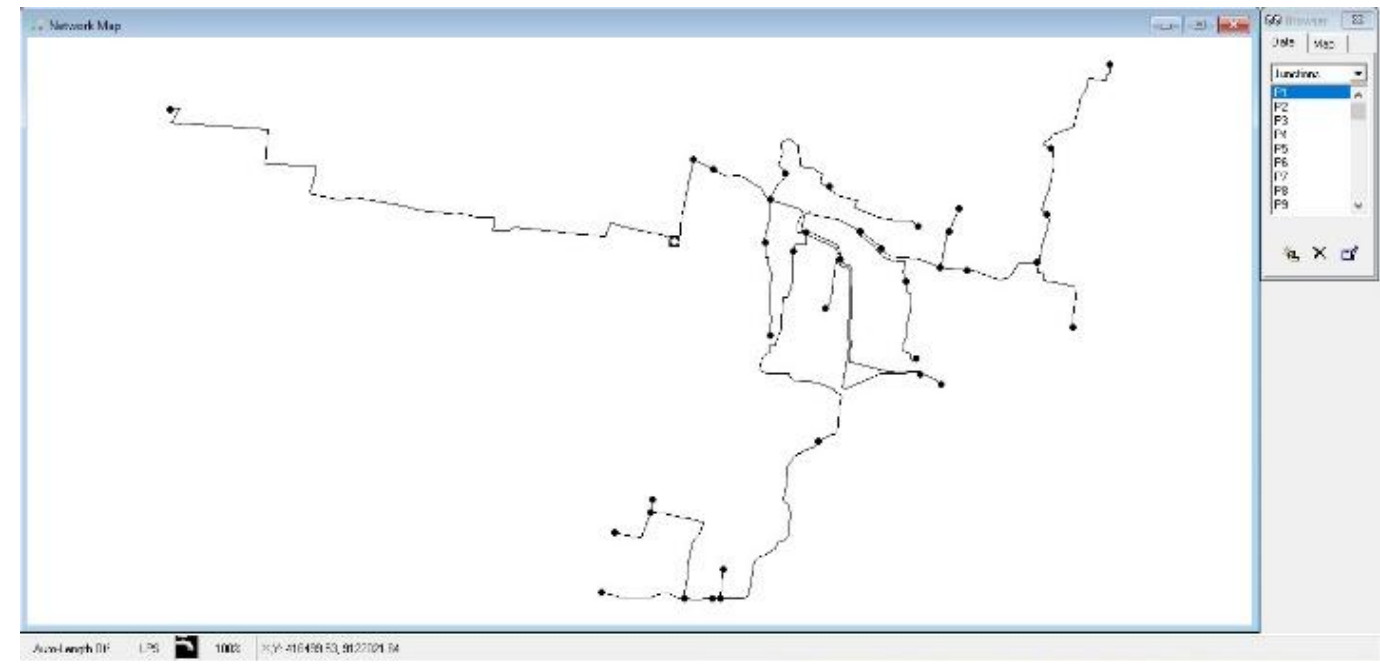

Gambar 5. Hasil Konversi Peta Jaringan

Peta Jaringan (Gambar 5) yang sudah ditampilkan di Epanet diperbaiki seperti penamaan pipa, penamaan node kemudian dilengkap informasi mengenai diameter pipa, jenis pipa, elevasi tiap node, kebutuhan air tiap node, dan aksesoris jaringan perpipaan yang belum ditampikan. Sistem Lendah memiliki satu reservoir sebagai sumber air yaitu intalasi pengolahan air lendah. Air yang telah diolah dipompa menuju tanki Jekeling yang memiliki kapasitas air sebesar 600 $\mathrm{m}^{3}$. Dalam sistem jaringan air dengan sistem pompa karakteristik pompa akan menentukan kinerja jaringan tersebut. Pada jaringan yang memiliki tanki pompa sebaiknya memiliki debit air yang karena akan mengefisienkan waktu operasi pompa sehingga pompa tidak cepat rusak. Sedangkan apabila jaringan tidak memiliki tanki kapasitas debit pompa disesuaikan dengan kebutuhan yang ada (Triatmadja, 2013).

Pompa yang digunakan pada Sistem Lendah menggunakan pompa merk 3 Phase Star Delta dengan satu titik dimana pada debit (Q) 40 liter/detik dapat mengangkat air $(\mathrm{Head} / \mathrm{H})$ sebesar 98 meter. Karena pompa yang dioperasikan secara simultan berjumlah dua buah maka didapatkan debit total sebesar 80 liter/detik. Kinerja pompa akan berpengaruh nantinya pada ketinggian level air di tanki. Semakin tinggi head/perbedaan ketinggian air yang harus diangkat maka semakin rendah debit yang bisa dihasilkan. Epanet sudah menghitung karakteristik tersebut sesuai dengan titik yang kita masukan. Hasilnya berwujud kurva karakteristik pompa yang dapat dilihat pada Gambar 6 berikut.

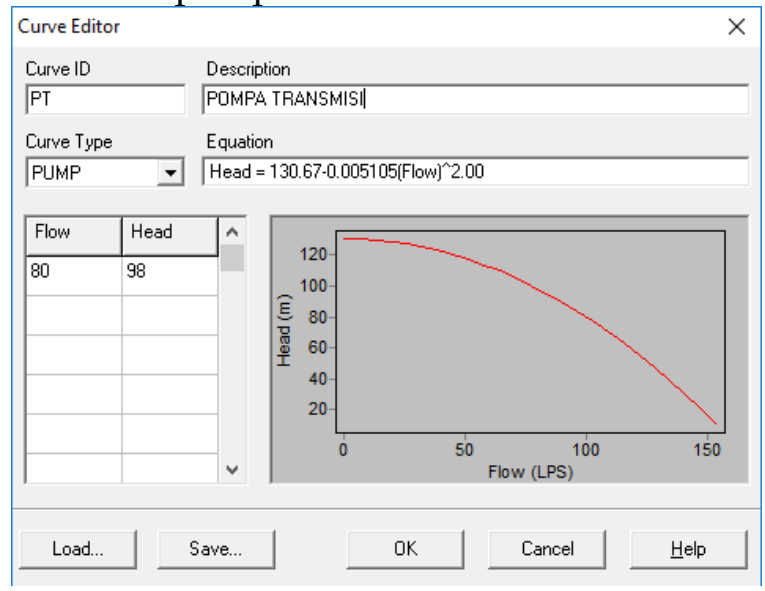

Gambar 6. Kurva Karakteristik Pompa 


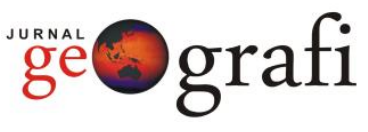

Pompa yang digunakan adalah pompa sentrifugal. Pompa jenis ini adalah pompa yang sangat banyak digunakan dalam dunia mekanikal dikarenakan mudah pengoperasiannya dan perawatannya. Pompa ini menaikkan air dengan merubah energi listrik menjadi energi kinetik untuk menggerakkan motor yang disambung ke propeler. Terjadi perbedaan tekanan antara air di sumber dengan propeler yang mengalami penurunan tekanan sehingga menggerakan air dari sumber air baku menuju propeler. Air dari propeler dilempar dengan energi yang besar menciptakan tekanan tinggi sehingga air memiliki tekanan untuk berpindah dari tempat yang rendah menuju tempat yang lebih tinggi dengan ketinggian dan debit tertentu. Chaurette (2015) mengemukakan dalam sistem pompa ada tiga hal penting yang perlu diperhatikan yaitu tekanan, aliran, dan friksi. Permen PUPR Nomor 27 Tahun 2016 memberikan pedoman bahwa pompa ini digunakan untuk kebutuhan head lebih dari 20 meter.

Agar penggunaan pompa dapat digunakan seefisien mungkin maka terdapat pengaturan penyalaan dan pemadaman pompa. Pompa dipadamkan ketikan level air di tanki maksimal, sedangkan pompa dinyalakan kembali ketika air di tanki berada pada level kritis. Pengaturan operasi pompa dapat dilihat pada Gambar 7.

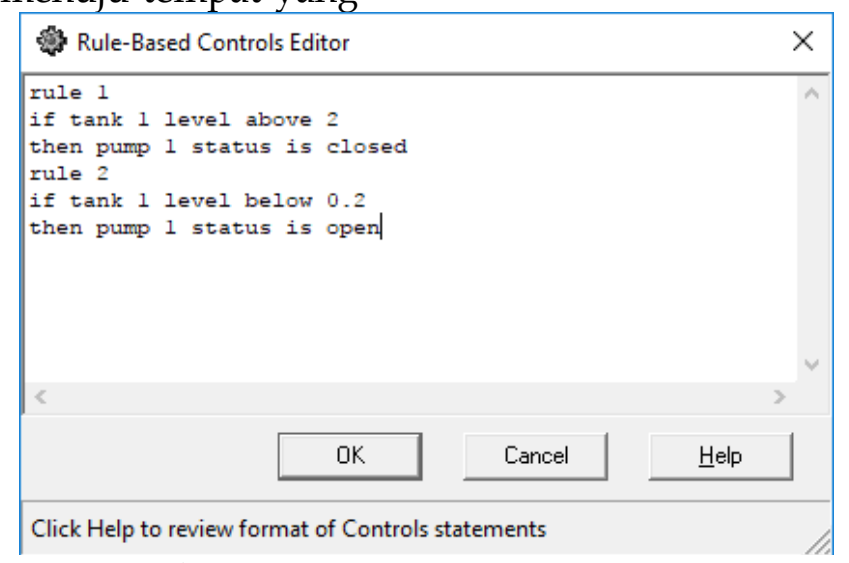

Gambar 7. Pengaturan Operasi Pompa

Hasil analisis Epanet (Gambar 8) selama 24 jam menunjukkan tidak adanya node yang mengalami tekanan negatif. Tekanan negatif menunjukkan bahwa air tidak dapat mengalir pada wilayah tersebut atau ada permasalahan di dalam jaringan. Permasalahan tekanan negatif ini biasanya diatasi dengan mengganti pipa yang dapat mengurangi kehilangan energi atau menambah pompa untuk menambah tekanan.

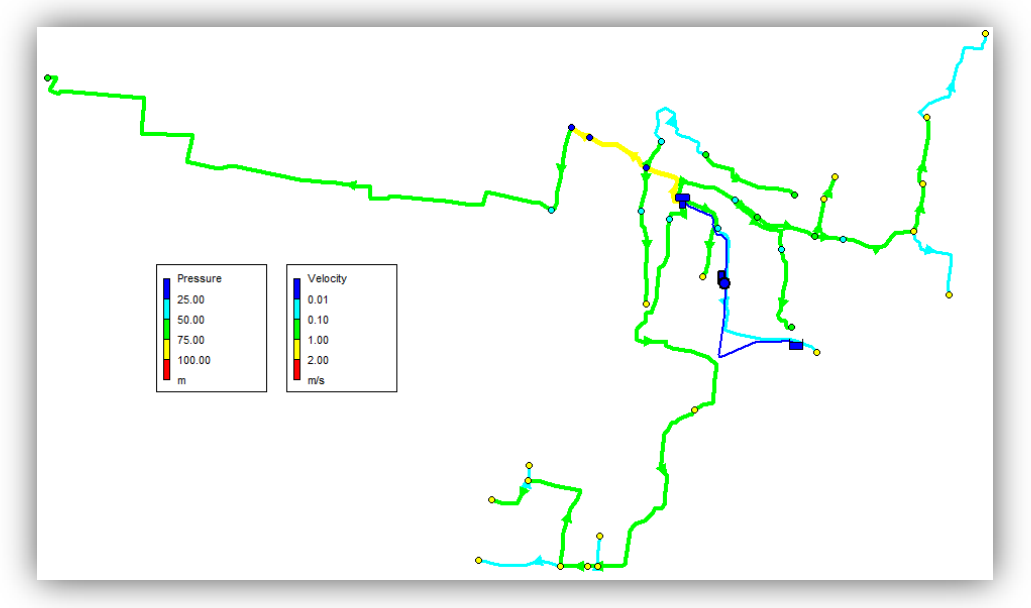

Gambar 8. Hasil Analsis Epanet 
Dalam hal ini jaringan Sistem Lendah secara teknis mampu mengalirkan air kepada pelanggan selama 24 jam. Hasil pengamatan grafik sisa tekanan di setiap node menunjukan bahwa sisa tekanan sepanjang hari relatif stabil. Kecuali di beberapa lokasi seperti Bandara dimana pada jam puncak pemakaian sisa tekanan relatif turun signifikan. Akan tetapi yang perlu diperhatikan adalah bahwa sisa tekanan di beberapa node sangat besar yaitu di atas 80 meter. Tekanan yang besar ini seperti sudah disyaratkan pada Tabel 1 akan mengakibatkan pipa tidak mampu menahan tekanan air. Akibatnya pipa relatif mudah mengalami kebocoran (Triatmadja, 2016). Untuk mengatasi hal tersebut terdapat beberapa cara yaitu mengganti pipa PVC menjadi pipa HDPE yang memiliki kekuatan menahan tekanan air lebih besar. Khususnya pada kawasan bandara dimana sisa tekanan relatif besar. Penggantian pipa pada daerah tersebut akan menciptakan efisiensi yang lebih besar karena pada dasarnya jaringan yang menuju ke arah bandara merupakan jaringan distribusi utama. Sedangkan pada internal sistem terlihat daerah yang terletak jauh dari tanki dengan perbedaan elevasi yang besar memiliki sisa tekanan yang besar. Untuk mengatasi hal ini dapat dipasar BTP (Bak Pelepas Tekanan). Penggunaan BTP untuk mengurangi pemborosan sisa tekanan. Selain menggunakan BTP dapat digunakan valve dengan jenis PRV (Pressure Reducing Valve).

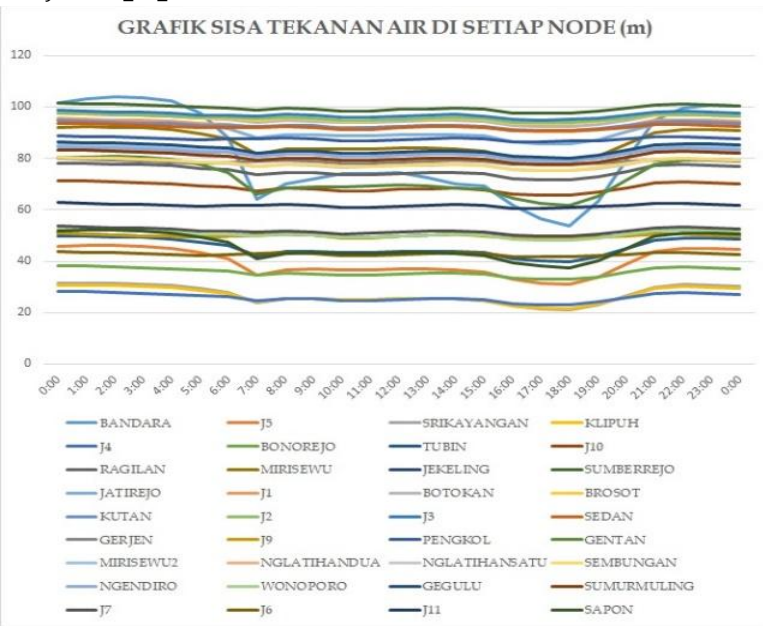

Gambar 9. Grafik Sisa Tekanan Air di Setiap Node

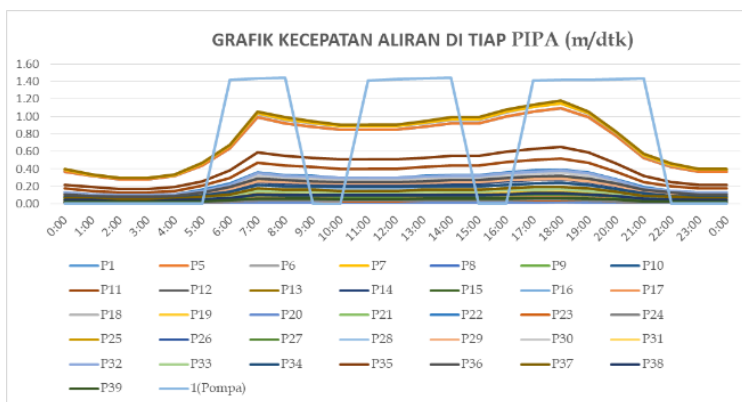

Gambar 10. Grafik Kecepatan Aliran di Tiap Pipa

Gambar 10 menunjukan kecepatan aliran dalam pipa. Sesuai dengan kriteria yang ditunjukan pada Tabel 1 bahwa pada pipa PVC kecepatan minimum sebesar $0,3 \mathrm{~m} /$ detik. Pada grafik tersebut masih banyak pipa yang memiliki 
kecepatan kurang dari yang disyaratkan. Kecepatan aliran air dalam pipa memungkinkan terjadinya endapan pada pipa yang jika bertumpuk dan terdekompresi secara terus menerus akan mengkerak dalam pipa dan mengurangi kapasitas pipa. Sedimen potensial yang mampu menganggu sistem ini adalah besi (Fe). Kandungan Fe pada sungai dan air tanah di Provinsi Daerah Istimewa Yogyakarta cukup tinggi. Biasanya air yang bersumber dari Sungai Progo memiliki Fe dan Mangan (Mn) (Tribun Jogja, 2016).

Tabel 2 Penggunaan Pompa

\begin{tabular}{|c|c|c|}
\hline No & Variabel & Nilai \\
\hline 1 & Usage Factor & 50 \\
\hline 2 & Efficiency Rata-rata (\%) & 75 \\
\hline 3 & $\mathrm{Kw}-\mathrm{Hr} / \mathrm{m}^{3}$ & 0.25 \\
\hline 4 & $\mathrm{Kw}$ Rata-Rata & 93.5 \\
\hline 5 & $\mathrm{Kw}$ Puncak & 100.64 \\
\hline 6 & Harga Satuan (Rp/Kwh) & 1,076 \\
\hline 7 & Biaya/Hari (Rp) & $1,207,272.00$ \\
\hline
\end{tabular}

Sumber: Hasil Analisis, 2017

Hasil analisis juga jaringan, kebutuhan jaringan, dan memperlihatkan biaya penggunaan pompa. Selama 24 jam pompa digunakan sebesar 50\% dari kapasitas maksimalnya sehingga potensi pengembangan pemenuhan air bersih untuk jaringan pada sistem ini masih sangat besar. Tingkat efisiensi rata-rata pompa ditentukan sebesar 75\%. Dengan menerapkan harga tarif dasar listrik untuk industri tertinggi maka didapatkan biaya operasional pompa sebesar 1 juta rupiah lebih. Secara satuan biaya pompa mencakup 15\% dari harga dasar jual air PDAM Kabupaten Kulon Progo yang saat ini mencapai Rp $1.700 / \mathrm{m}^{3}$.

Jika dilihat secara umum adanya tanki dalam Sistem Lendah memberikan sistem ini efisiensi dalam penggunaan pompa. Hal ini dikarenakan wilayah pelayanan sistem ini relatif lebih tinggi dari sumber air. Akan tetapi peletakan tanki pada lokasi yang sangat tinggi telah memberikan sisa tekanan air yang sangat besar sehingga terjadi pemborosan tekanan dan rawan akan kebocoran. Penggunaan diameter pipa yang relatif besar membuat kecepata aliran pipa lambat membuat air memiliki kemungkinan mengendapkan kandungan tersuspensi. Pemanfaatan diameter dan jenis pipa harus disesuaikan dengan tipe

proyeksi di masa datang. Selain akan meningkatkan efektifitas teknis penyediaan air juga akan menghemat pengeluaran baik untuk modal dan operasional.

\section{KESIMPULAN}

SIG memberikan peningkatan efisiensi dalam mengevaluasi kinerja jaringan perpipaan. Integrasi SIG dengan Epanet mampu membuat pemilik pekerjaan mengevaluasi jaringan dengan ketelitian geografis yang tinggi. Sistem Lendah dengan sistem pompa-gravitasi mampu menyediakan air bersih selama 24 jam. Sisa tekanan yang besar di beberapa node menyebabkan sistem ini rawan akan tingkat kebocoran yang tinggi. Kecepatan aliran yang rendah menyebabkan potensi endapan dalam pipa besar.

\section{UCAPAN TERIMAKASIH}

Terimakasih penulis ucapkan kepada Bapak Heri Selaku Kepala Seksi Perencanaan dan Program PDAM Kabupaten Kulon Progo yang berkenan membantu penulis mendapatkan data yang dibutuhkan. Secara umum penulis mengucapkan terima kasih kepada PDAM 
Kabupaten Kulon Progo yang bersedia menjadi objek penelitian penulis.

\section{DAFTAR PUSTAKA}

Awalin, L.K. dan Sukojo, B.M. (2014) Pembuatan dan Analisa Sistem Informasi Geografis Distribusi Jaringan Listrik (Studi Kasus: Surabaya Industrial Estate Rungkut di Surabaya). Makara Teknologi, 7:33-44.

Bappeda Kabupaten Kulon Progo. (2014). Rencana Induk Sistem Penyediaan Air Minum (RISPAM) Kabupaten Kulon Progo. Wates: Pemerintah Daerah Kabupaten Kulon Progo.

Chandapillai, J., \& Sudheer, KP. Saseendran, S. (2011). Design of Water Distribution Network for Equitable Supply. Water Resources Management, 26:391-406.

Dharmasetiwan, Martin. (1993). Sistem Perpipaan Distribusi Air Minum. Jakarta Selatan: Ekamitra Engineering.

Driyono, AR. (2016). Evaluasi Desain Jaringan Perpipaan SPAM (Sistem Penyediaan Air Minum) Regional Sitem Bantar. Skripsi.Yogyakarta: Universitas Gadjah Mada.

Dueker, K.J. dan Kjerne, D. (1989). Multipurpose Cadastre: Terms and Definitions. Fall Church VA: AMaerican Society for Photogrammetry and Remote Sensing and American Congress on Surveying and Mapping.

Kementerian Pekerjaan Umum dan Perumahan Rakyat. (2016). Peraturan Menterian No. 27 Tahun 2016 tentang Penyelenggaraan Sistem Penyediaan Air Minum. Berita Negara RI Tahun 2016, No. 1154. Jakarta: Biro Hukum Kementerian Pekerjaan Umum dan Perumahan Rakyat.

Kreveld, M. (1997). Digital Elevation Models and TIN algorithms. Algorithmic Foundations of Geographic Information Systems, 37-78. Berlin: Springer-Verlag.
Lukenga, Walter. (2015). Water Resource Management.Munster: Walter Lukenga \& bookboon.com

Maidment, David R. (2002). Arc Hydro GIS for Water Resouces. Redland Claifornia: ESRI.

Maulana, MUB. (2011). Kajian Penyediaan Air Bersih untuk Bandara Kulon Progo. Tesis. Yogyakarta: Unversitas Gadjah Mada.

Mohaptra, S. Sargaonkar A. Labhasetwar, PK. (2014). Distribution Network Assessment using Epanet for Intermittent and Countinous Water Supply. Water Resources Management, 28:3745-3759.

Nguyen, G., Šipková, V., Krammer, P., Hluchý, L., Dobrucký, M., Tran, V., \& Habala, O. (2016). Integrated system for hydraulic simulations. Computing and Informatics, 34(5), 1065-1088.

Rachmawati, Azizah. (2010). Aplikasi Sistem Informasi Geografis untuk Evaluasi Sistem Jaringan Drainase di Sub DAS Lowokwaru Kota Malang. Jurnal Rekayasa Sipil, 4:1978-5658.

Republik Indonesia. (2015). Peraturan Pemerintah No. 122 Tahun 2015 tentang Sistem Penyediaan Air Minum. Lembar Negara RI Tahun 2015, No. 345. Jakarta: Kementerian Sekretariat Negara RI.

Shen, H., \&McBean E. 2010. An ArcGis Tool for Rapid Contaminant Source Identification. Water Distribution System Analysis Conference 2010. Tucson AZ: American Society of Civil Engineers.

Triatmadja, Radianta. (2013). Hidraulika Sistem Jaringan Perpipaan Air Minum. Yogyakarta: Beta Offset.

Triatmadja, Radianta. (2016). Teknik Penyediaan Air Minum Perpipaan. Yogyakarta: Gadjah Mada University Press.

Tribun Jogja. (2016). Air Sungai Progo akan Didistribusikan ke Warga Yogya.http://jogja.tribunnews.com/20 16/06/16/air-sungai-progo-akan- 
didistribusikan-ke-warga-yogya.

Diakses tanggal 14 Januari 2018.

Wang, Yinsong. (2017). Google Earth

Elevation Data Extraction and

Accuracy for Transportation

Applications. Plos One Journals, 4. 